\title{
Comparative Evaluation of Eurytoma schreineri Schr. Attack Frequency on Transgenic and Two Conventional Plum Varieties
}

\author{
Luminita Antonela ZAGRAI, Ioan ZAGRAI* \\ Research and Development Station for Fruit-Tree Growing Bistrita, 3 Drumul Dumitrei Nou, Bistriţa, \\ 420127, Romania \\ *corresponding author: izagrai@yahoo.com \\ BulletinUASVM Horticulture 77(1) / 2020 \\ Print ISSN 1843-5254, Electronic ISSN 1843-5394 \\ DOI:10.15835/buasvmcn-hort: 2019.0032
}

\begin{abstract}
The plum seed wasp (Eurytoma schreineri Schr.) is a polyphagous pest that can cause significant damages to the plum crop. A transgenic plum variety, resistant to Plum pox virus, was evaluated to the attack frequency of E. schreineri in the context of reduced number of insecticide treatments against aphids, in comparison with two conventional plum varieties. The most affected variety by plum seed wasp, for two consecutive years, was 'Stanley', followed by 'Reine Claude d'Althan', and then 'HoneySweet' transgenic plum. The differences between variants were statistically assured.
\end{abstract}

Keywords: Eurytoma schreineri, plum seed damage, transgenic plum

\section{Introduction}

Eurytoma schreineri Schr. has one generation per year and overwinters as a fully developed larva in the stone of infested fruits. The affected fruits have a weak development and begin to fall as they approach to maturation, and then mummify. 'HoneySweet' transgenic plum was created as a necessity for an effective control to Plum pox virus in endemic areas, and has many advantages derived from its resistance to the virus (Scorza et al., 2013), among these being the possibility to reduce the number of treatments with insecticides against aphids (Zagrai et al., 2019). In this context, the studies have been extended to assess its behaviour to the Eurytoma schreineri attack.

\section{Materials and methods}

The study was performed within an experimental plot containing twenty-four trees of 'HoneySweet' transgenic plum and twenty-four trees of two conventional plum varieties: 'Stanley' and 'Reine Claude d'Althan'. Only four treatments with insecticides were applied instead of usually 7-8 ones during the two years. The frequency of Eurytoma schreineri attack was determined along two consecutive years (2017-2018), on all fruits 


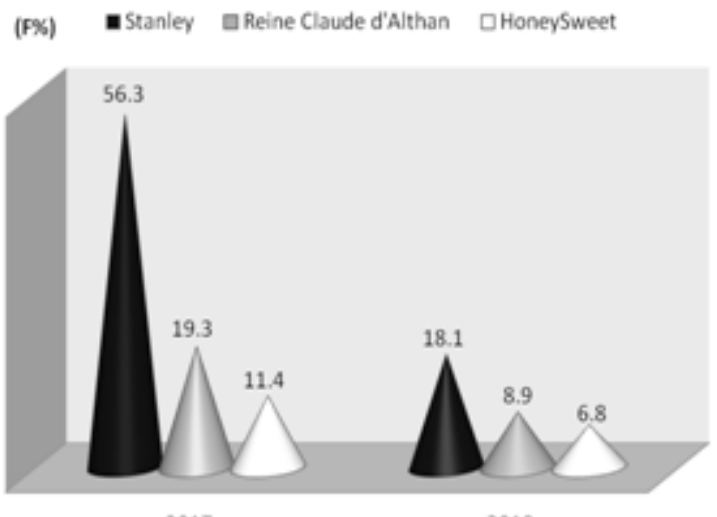

year 2017

year 2018

Figure 1. Attack frequency (F\%) of E. schreineri on transgenic and conventional plum varieties

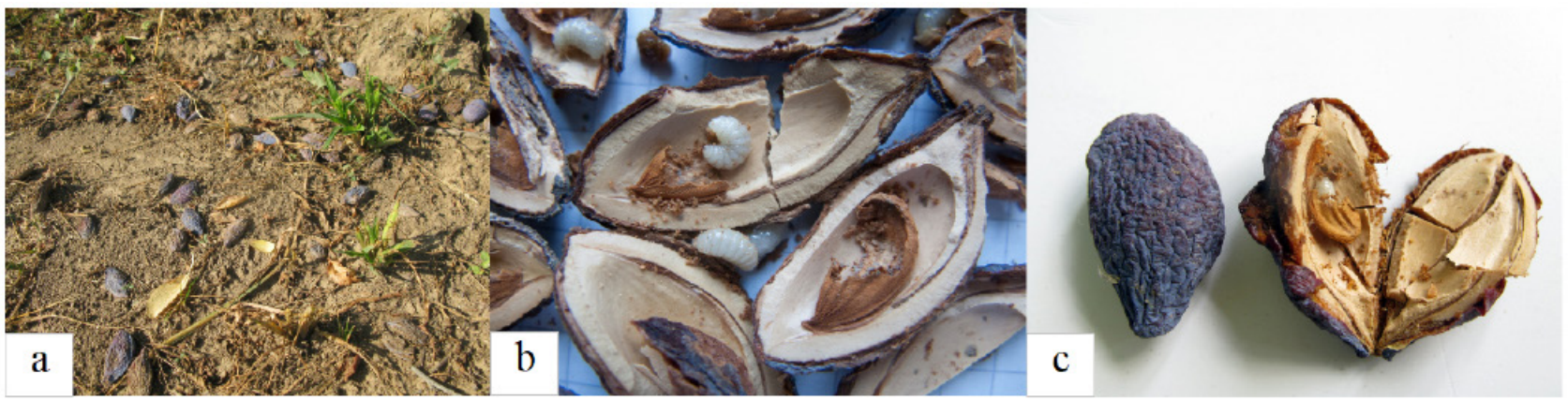

Figure 2. Massive falls of fruits caused by Eurytoma schreineri (a) and damages produced by pest (b,c) on Stanley (2017) - original

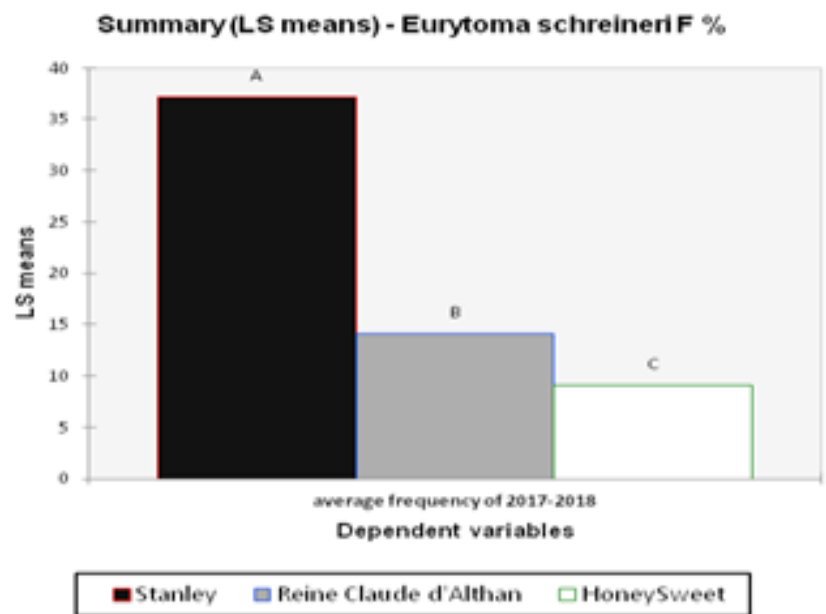

Figure 3. Duncan test results of attack frequency (F\%) of E. schreineri on three plum varieties

from each tree. Then a comparison of behaviour between transgenic and the two conventional varieties has been made by Duncan test.

\section{Results and discussions}

The results obtained along the two vegetative periods of 2017 and 2018 are shown in Figure 1.
In 2017, results indicated the presence of Eurytoma schreineri in all three varieties with a high predilection for 'Stanley' $(\mathrm{F} \%=56.3)$, being considered a massive attack of seed wasp (Fig. 2) with negative consequences on yield

The other two varieties were also affected by this pest, but the frequency of attack was 
much lower, respectively $19.3 \%$ on 'Reine Claude d'Althan' and $11.4 \%$ on 'HoneySweet'. In 2018, the attack frequency was much diminished in all three varieties, probably due to the decreasing of biological reserve by elimination of the affected fruits fallen on the ground in the previous year. However, the frequency of E. scherineri keeps the previous order, the most intense damage was recorded in 'Stanley' (18.1\%), followed by 'Reine Claude d'Althan' (8.9\%) and 'HoneySweet' (6.8\%).

The overall results show that 'Stanley' was the most affected variety by plum seed wasp. 'HoneySweet' and 'Reine Claude d'Althan' were also affected but with significantly lower values than 'Stanley' (Fig. 3).

\section{Conclusions}

A reduced number of insecticide treatments could lead to a high damage of yields in 'Stanley'. Although with significantly lower values of attack frequency, 'Reine Claude d'Althan' and 'HoneySweet' can also be affected by Eurytoma schreineri.

Acknowledgments. This work was supported by Ministry of Agriculture and Rural Development, ADER 2020 program, Contract 4.1.3/2015.

\section{References}

1. Scorza R, Callahan A, Dardick C, Ravelonandro M, Polak J, Malinowski T, Zagrai I, Cambra M, Kamenova V (2013). Genetic engineering of Plum pox virus resistance 'HoneySweet' plum - from concept to product. Plant Cell, Tissue and Organ Culture, 115: 1-12.

2. Zagrai I, Zagrai L, Ravelonandro M, Ralph S, Jakab Z, Guzu G (2019). Assessment on the potential decrease of insecticide treatments against aphids in 'HoneySweet' plum [Prunus domestica (1.)] plantings. Acta Hort.(in press). 